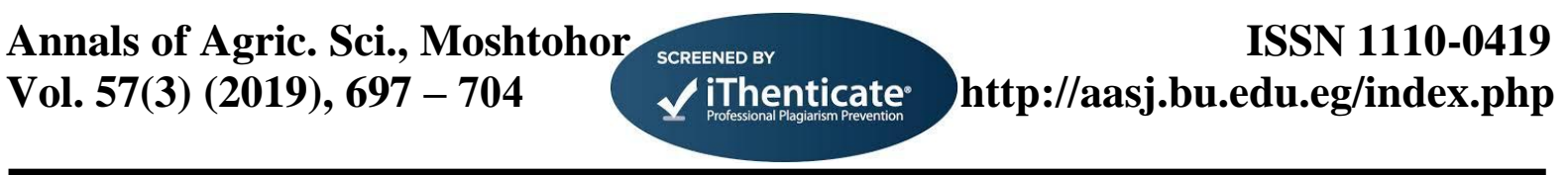

\title{
Pan Bread Quality as Affected by the Addition of Ajwain and Thyme Powders
}

\author{
Hanaa A. R. Mohamed ${ }^{\mathrm{a}}$, Y.I.Sallam ${ }^{\mathrm{b}}$, A.S.El-Leithyc and Safaa E. Aly ${ }^{\mathrm{a}}$ \\ ${ }^{a}$ Food Technology Research Institute, Giza, Egypt \\ ${ }^{\mathrm{b}}$ Food Technology Dept., Fac. of Agric., Cairo Univ., Giza, Egypt \\ ${ }^{\mathrm{c}}$ Orn. Hort. Dept., Fac. of Agric., Cairo Univ., Giza, Egypt \\ Corresponding author: hanaa.ahmed1981@yahoo.com
}

\begin{abstract}
Consumer acceptability and pan bread quality as influenced by the addition of ajwain (TrachyspermumammiL.) and thyme (Thymus vlugaris) leaves powders were investigated. Ajwain and thyme powders were used to replace 2, 4 and $6 \%$ of pan bread wheat flour. Levels at 2 and $4 \%$ were acceptable by panelists. Meanwhile, substitutes at level 6\% showed the lowest acceptability score comparing to control samples. Specific volume of pan bread samples were significantly $(\mathrm{p}<.05)$ decreased, expect $\mathrm{A}_{2}$ sample which containing $2 \%$ ajwain powder. Sample containing $4 \%$ thyme $\left(\mathrm{T}_{4}\right)$ recorded the lowest specific volume $3.51 \mathrm{~cm}^{3} / \mathrm{g}$, while control sample recorded the highest value $4.11 \mathrm{~cm}^{3} / \mathrm{g}$. Crumb color was significantly affected $(\mathrm{p}<.05)$, increasing replacement level decreasing $\mathrm{L}^{*}$ values and increasing $\mathrm{b}^{*}$ values. That means the darkness gradually increased, and yellowness decreased. The $a^{*}$ values for ajwain increased while, a* values of thyme decreased, indicated that pan bread contained ajwain become more redness, while thyme pan bread become more greenness. Textural profile analysis showed an increase in hardness and reduced in resilience with no significant differences observed, except $\mathrm{T}_{4}$ pan bread sample which recorded $8.19 \mathrm{~N}$ and 0.18 for hardness and resilience, respectively comparing to control sample which recorded $7.50 \mathrm{~N}$ and 0.20 for hardness and resilience, respectively. Concerning to cohesiveness, $\mathrm{T}_{4}$ sample recorded the lowest score 0.54 with no significant differences comparing to control sample which recorded 0.62 .
\end{abstract}

Key words: Ajwain; Thyme; Pan bread quality; Consumer acceptance.

\section{Introduction}

Bread in its various forms is one of the most consumed food products and becoming an essential product of the international food market (Saranraj and Geetha, 2012; Menon et al., 2015 and Bolarinwaet al., 2019). According to the Codex Alimentarius, bread is the product resulting from baking dough obtained by mixing flour and water, with or without addition of edible salt, fermented bakery's yeast (Heras-Mozoset al., 2019).

Medical and aromatic plants have been used for a long time to improve the sensory characteristics of food, as well as a preservatives substance and for their nutritional and healthy properties (Nieto, 2017). Medical and aromatic plants are generally recognized as safe (GRAS) and are widely used for their antioxidant activities and as alternative synthetic preservatives Ajwain (Trachyspermumammi) belong to family Apiaceae, the most utilized part is ajwain seeds (Singh et al., 2004), thymol is the major compound. These seeds are used in Asian cooking and for baking biscuits, bread and in bean dishes (Mood et al., 2014). Lamiaceae is one of the most important families in the production of essential oils with antioxidants and antimicrobial properties (Nieto, 2017), thyme (Thymus vulgaris) belong to this family.

There are several baking studies for bakery products that incorporate with medical and aromatic plants, such as (Boehmerianivea L.) ramie powder
(Lee and Joo, 2012), cinnamon and orange extracts (Ahmed and Hussein, 2012), Oregano (Dhillon et al., 2013), Chokeberry Polyphenols Extract (Bialek et al., 2016).and green tea powder (Ning et al., 2019).

The objective of this study was to evaluate the quality characteristic of pan bread incorporated with ajwain seed powder and thyme leaves powder at different levels, as well as to determine the organoleptic acceptability of the product.

\section{Materials and Methods}

\section{Materials:}

Ajwain (Trachyspermumammi (L.) seeds, thyme (Thymus vulgaris) leaves were purchase from Harraz for Food Industry and Natural Products, Cairo, Egypt. wheat flour $72 \%$ extract, instant yeast, salt and sugar were purchased from the local market. Sunflower oil was obtained from Arma for Food Industry, $10^{\text {th }}$ of Ramadan City, Egypt.

\section{Methods:}

a. Preparation and formulation of pan bread samples

The straight dough method for pan bread production was carried out according to the method described by (AACC, 2002) with some modification at Special Unit for Bakery Products Food Technology Research Institute (FTRI), Giza, Egypt. Basic dough formula of $1000 \mathrm{~g}$ flour basis was 
consisted of instant yeast (15g), sugar (20 g), salt $(12 \mathrm{~g})$, sunflower oil $(4 \mathrm{~g})$ and the required amount of water. The blends of wheat flour with ajwain and thyme as shown in Table (1) and all other ingredients were mixed together. The resulted dough was let to rest for $30 \mathrm{~min}$ (first proofing), then divided to (350 gm) pieces, rolled and molded in molding. Each piece was placed in baking pans $(28 \times 12 \times 7 \mathrm{~cm})$ tightly greased to prevent the loaves from sticking pans and was let to ferment for $60 \mathrm{~min}$ in a cabinet at $30^{\circ} \mathrm{C}$ and $80-85 \%$ relative humidity, then baking process was carried out in electrically heated oven at $230^{\circ} \mathrm{C}$ for $25-30 \mathrm{~min}$. After baking, loaves were separated from the baking pans and allowed to cool for $2 \mathrm{hr}$. at room temperature $\left(28^{\circ} \mathrm{C} \pm 5^{\circ} \mathrm{C}\right)$ for physical and organoleptic evaluation. The produced loaves were weighted, and the volume was measured by the rapeseed displacement method according to (AACC, 2002).

Table 1. Pan bread ingredients

\begin{tabular}{|c|c|c|c|c|c|c|}
\hline Sample & $\begin{array}{l}\text { Flour } \\
(\mathrm{g})\end{array}$ & $\begin{array}{c}\text { Ajwain/or thyme } \\
\text { powder } \\
\text { (g) }\end{array}$ & $\begin{array}{c}\text { Yeast } \\
(\mathrm{g})\end{array}$ & $\begin{array}{c}\text { Sunflower oil } \\
\text { (g) }\end{array}$ & $\begin{array}{c}\text { Salt } \\
(\mathrm{g})\end{array}$ & Sugar (g) \\
\hline Control & 1000 & - & 15 & 4 & 12 & 20 \\
\hline $\mathbf{A}_{2}$ & 980 & 20 & 15 & 4 & 12 & 20 \\
\hline $\mathbf{A}_{4}$ & 960 & 40 & 15 & 4 & 12 & 20 \\
\hline $\mathbf{A}_{6}$ & 940 & 60 & 15 & 4 & 12 & 20 \\
\hline $\mathbf{T}_{2}$ & 980 & 20 & 15 & 4 & 12 & 20 \\
\hline $\mathbf{T}_{4}$ & 960 & 40 & 15 & 4 & 12 & 20 \\
\hline$T_{6}$ & 940 & 60 & 15 & 4 & 12 & 20 \\
\hline
\end{tabular}

*Control: bread without any addition; $\mathrm{A}_{2}, \mathrm{~A}_{4}$ and $\mathrm{A}_{6}$ : pan bread contains ajwain seed powder $2 \%, 4 \%$ and $6 \%$, respectively. $\mathrm{T}_{2}, \mathrm{~T}_{4}$ and $\mathrm{T}_{6}$ pan bread: contain $2 \%, 4 \%$ and $6 \%$ thyme leave powder, respectively.

\section{b. Overall acceptability}

A seven-point hedonic scale was used to evaluate the overall acceptability of the bread formulations; where 1 = dislike very much, 2 = dislike moderately, $3=$ dislike slightly, $4=$ neither like nor dislike, $5=$ like slightly, $6=$ like moderately and $7=$ like very much as suggested by Wójcik et al., (2017), to determine the acceptable levels of replacement. Breads were considered acceptable if their mean scores for overall acceptability were above 4 (neither like nor dislike).

\section{c. Sensory evaluation}

The Organoleptic characteristics of the pan bread attributes were evaluated by fifteen panelists of Food Technology Research Institute (FTRI) for color (20), taste (20), odor (20), appearance (20) and texture (20) as described by Seleem et al., (2014).

\section{d. Physical analysis}

\section{Specific volume of pan bread loaves}

After baking and cooling for $2 \mathrm{hr}$. The bread volume was measured according to the method of AACC (2002); weights were recorded by using decimal digital weighing scale. The specific volume was calculated as the ratio between the volume and the weight of the bread $\left(\mathrm{cm}^{3} / \mathrm{g}\right)$. Three replicates of each sample were analyzed.

\section{Texture profile analysis}

Texture parameters (hardness, cohesiveness and resilience) of pan bread samples were measured objectively by using a texture analyzer CT3 Texture Analyzer (Version 2.1, 10000 Gram unit, Brookfield,
Engineering Laboratories, Inc. USA), according to method 74-09 (A.A.C.C., 2000) and as described by Peng et al., (2010), whereas one slice of pan bread approximately $25 \mathrm{~mm}$ thick or two slices, each approximately $12.5 \mathrm{~mm}$ thick could be used. Set up a $36 \mathrm{~mm}$ diameter cylindrical probe at a test speed of 2 $\mathrm{mm} / \mathrm{s}$. The location of testing was the center of the bread slices avoiding non-representative areas of crumb. Sample was subjected to $40 \%$ deformation and trigger load 5g. Parameters (graph and data) were automatically recorded by computer software (TA-CT-PRO Software). Hardness (N or g), cohesiveness and resilience were also recorded. Test was a total of three samples per treatment undergo. Results were calculated as the average of the three determinations per treatment.

\section{Color measurement}

The color (CIE* system) of pan bread crumb were determined using a Chroma-meter (Minolta CR-400, Minolta, Osaka, Japan) according to the method of Zhu et al., (2016). Where, L* indicates the brightness-darkness. While positive and negative $\mathrm{a}^{*}$ indicates the redness-greenness and $b^{*}$ indicates yellowness-blueness.

\section{e. Statistical analysis}

The results were statistically analyzed using CoState statistical software (CoHort Software, Monterey, CA, USA). The statistical calculations included the analysis of variance (ANOVA) one way completely randomized. $\mathrm{p}<0.05$ was considered to be significant using Duncan's test. All data were 
expressed as means values \pm Standard Deviation (SD), as described by Snedecor and Cochran (1982).

\section{Results and Discussion}

\section{Consumer acceptability}

The consumer acceptability was conducted to evaluate the acceptable level of ajwain and thyme powders. Data in Table (2)cleared that the treatment $\mathrm{A}_{2}$ and $\mathrm{T}_{2}$ revealed no significant difference compared to control sample, while there was a significant difference $(\mathrm{p}<0.05)$ between control and other treatments.

Table 2. Consumer acceptability of pan bread samples

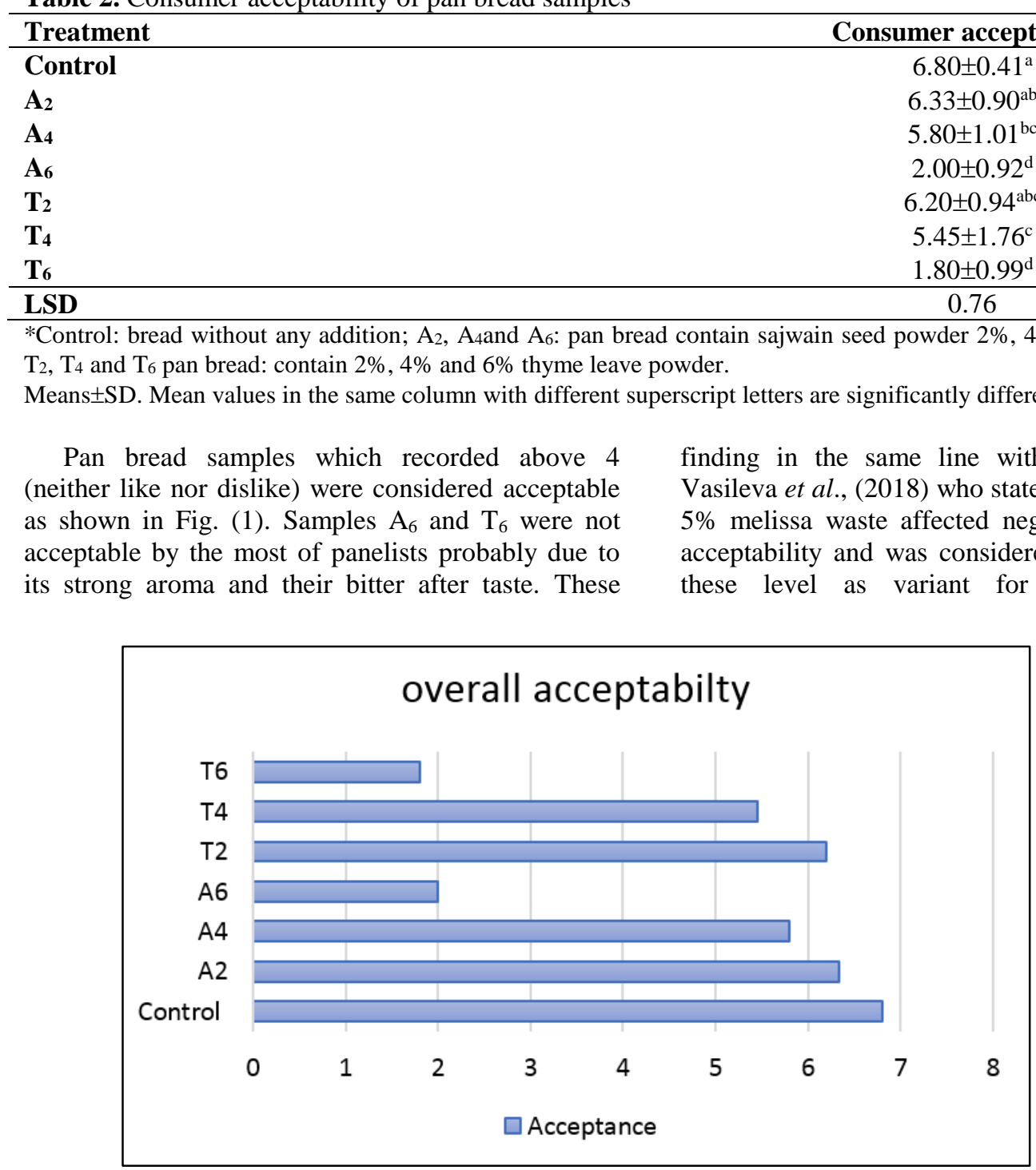

Fig. 1 The overall acceptability of pan bread samples

\section{Sensory evaluation}

The overall bread quality was evaluated for the sensory attributed of their taste, color, odor, and texture. The mean sensory evaluated values are presented in Table (3). The results showed that the control sample scored the best results for all attributes compared to other samples, except in odor, whereas, $\mathrm{A}_{2}$ sample recorded the best score. In general, no significant difference in all sensory attributes was observed between bread with $2 \%$ replacement and control sample. The samples at $6 \%$ replacement had the lowest score in taste with significant differences $(\mathrm{p}<0.05)$ compared to other samples. The acceptable blends were selected to evaluate the quality characteristics of pan bread. These results closed to that obtained by Seleem and Mohamed (2014) who found that incorporated thyme at level $2 \%$ showed significant differences only in general appearance. Also, Abd El-Megeid et al., (2009) found that the best level of fortification green tea which had the highest scores was recorded for $2 \%$ fortified bread followed by $4 \%$ fortified bread, while $6 \%$ fortified bread had the lowest scores. 
Table 3. Sensory evaluation of pan bread samples

\begin{tabular}{|c|c|c|c|c|c|}
\hline Sample & Taste & Color & Odor & Appearance & Texture \\
\hline Control & $18.80 \pm 0.56^{\mathrm{a}}$ & $18.87 \pm 0.74^{\mathrm{a}}$ & $18.27 \pm 0.88^{\mathrm{ab}}$ & $18.33 \pm 0.90^{\mathrm{a}}$ & $18.53 \pm 0.74^{\mathrm{a}}$ \\
\hline $\mathbf{A}_{2}$ & $18.00 \pm 0.75^{\mathrm{ab}}$ & $18.27 \pm 0.88^{\mathrm{a}}$ & $18.73 \pm 0.79^{a}$ & $18.60 \pm 0.63^{\mathrm{a}}$ & $18.46 \pm 0.51^{\mathrm{a}}$ \\
\hline $\mathbf{A}_{4}$ & $17.60 \pm 0.91^{\mathrm{b}}$ & $18.53 \pm 0.74^{\mathrm{a}}$ & $17.73 \pm 0.45^{\mathrm{bc}}$ & $18.00 \pm 0.53^{\mathrm{ab}}$ & $17.40 \pm 0.63^{b}$ \\
\hline A6 & $9.33 \pm 2.16^{\mathrm{c}}$ & $18.33 \pm 0.90^{\mathrm{a}}$ & $16.53 \pm 0.83^{\mathrm{d}}$ & $17.53 \pm 0.63^{b c}$ & $17.13 \pm 0.64^{b c}$ \\
\hline $\mathbf{T}_{2}$ & $18.3 \pm 0.72^{\mathrm{ab}}$ & $16.93 \pm 0.70^{\mathrm{b}}$ & $18.13 \pm 0.83^{\mathrm{ab}}$ & $17.13 \pm 0.74^{\mathrm{c}}$ & $18.06 \pm 0.59^{a}$ \\
\hline $\mathbf{T}_{4}$ & $17.47 \pm 0.83^{\mathrm{b}}$ & $13.47 \pm 1.06^{\mathrm{c}}$ & $17.33 \pm 0.82^{\mathrm{c}}$ & $15.53 \pm 0.91^{\mathrm{d}}$ & $16.80 \pm 0.67^{\mathrm{c}}$ \\
\hline $\mathbf{T}_{6}$ & $9.13 \pm 1.60^{c}$ & $9.13 \pm 1.80^{\mathrm{d}}$ & $16.27 \pm 0.88^{\mathrm{d}}$ & $13.46 \pm 1.55^{\mathrm{e}}$ & $15.60 \pm 0.83^{\mathrm{d}}$ \\
\hline LSD & 0.87 & 0.75 & 0.57 & 0.65 & 0.48 \\
\hline
\end{tabular}

\section{Specific volume}

Pan bread specific volume was ranged between $4.11 \mathrm{~cm}^{3} / \mathrm{g}$ (control) to $3.51 \mathrm{~cm}^{3} / \mathrm{g}$ for $\left(\mathrm{T}_{4}\right)$ treatment as shown in Table 4. From the obtained result it could be noticed that the specific volume tends to decrease with increasing substitution level. This finding is in agreement with those obtained by Feili et al., (2013) and Ning et al., (2017). Significant differences $(\mathrm{p}<0.05)$ was observed between control and pan bread samples except $\left(\mathrm{A}_{2}\right)$ sample. This decrease probably due to the effect of ajwain and thyme on gluten network (Schmiele et al., 2012 and Odunlade et al., 2017). Increasing quantity of yeast used or longer proofing time could probably improve the volume (Odunladeet al., 2017). Also, Maktoufet al., (2016) reported that lipids had positively affects the specific volume due to their ability to form lipid monolayers at the gas/liquid interphase of the gas cells.

Table 4. Specific volume of pan bread

\begin{tabular}{lc}
\hline Treatment & Specific volume $\left(\mathbf{c m}^{\mathbf{3}} / \mathbf{g}\right)$ \\
\hline Control & $4.11 \pm 0.10^{\mathrm{a}}$ \\
$\mathbf{A}_{2}$ & $3.99 \pm 0.11^{\mathrm{ab}}$ \\
$\mathbf{A}_{4}$ & $3.89 \pm 0.02^{\mathrm{b}}$ \\
$\mathbf{T}_{2}$ & $3.85 \pm 0.10^{\mathrm{b}}$ \\
$\mathbf{T}_{\mathbf{4}}$ & $3.51 \pm 0.03^{\mathrm{c}}$ \\
\hline LSD & 0.15 \\
\hline
\end{tabular}

*Control bread without any addition; $\mathrm{A}_{2}$ and $\mathrm{A}_{4}$ : pan bread contain sajwain seed powder $2 \%$ and 4 , respectively. $\mathrm{T}_{2}$ andT $\mathrm{T}_{4}$ pan bread: contain 2 and $4 \%$ thyme leave powder.

Means \pm SD. Mean values in the same column with different superscript letters are significantly different $(\mathrm{P}<0.05)$.

\section{Effect of ajwain and thyme powders on pan bread crumb color}

The color values of pan bread crumb are presented in Table 5. All color data were expressed as L* (lightness - darkness), a* (redness - greenness) and $\mathrm{b}^{*}$ (yellowness - blueness) values. The obtained results in Table (5) showed that crumb color of pan bread was significantly $(\mathrm{p}<0.05)$ affected by replacement level of ajwain and thyme powders. From the results it could be noticed that the increase level of ajwain and thyme significantly decreased $\mathrm{L}^{*}$ values. Mean while, $b^{*}$ values increased. This finding is in agreement with those obtained by Lee and Joo, (2012) and Zhu et al., (2016).

Table 5. Effect of ajwain and thyme powders on pan bread crumb color

\begin{tabular}{|c|c|c|c|}
\hline \multirow{2}{*}{ Sample** } & \multicolumn{3}{|c|}{ Crumb } \\
\hline & $\mathrm{L}^{*}$ & $a^{*}$ & $\mathrm{~b}^{*}$ \\
\hline Control & $78.35 \pm 0.70^{\mathrm{a}}$ & $0.84 \pm 0.07^{\mathrm{c}}$ & $16.55 \pm 1.11^{\mathrm{d}}$ \\
\hline $\mathbf{A}_{2}$ & $68.90 \pm 0.40^{\mathrm{b}}$ & $2.33 \pm 0.11^{\mathrm{b}}$ & $21.28 \pm 0.66^{c}$ \\
\hline $\mathbf{A}_{4}$ & $65.15 \pm 1.29^{c}$ & $3.16 \pm 0.16^{\mathrm{a}}$ & $23.36 \pm 0.78^{b}$ \\
\hline $\mathbf{T}_{2}$ & $65.61 \pm 0.50^{c}$ & $0.34 \pm 0.02^{\mathrm{d}}$ & $24.29 \pm 0.78^{\mathrm{ab}}$ \\
\hline $\mathbf{T}_{4}$ & $61.13 \pm 0.43^{\mathrm{d}}$ & $-0.37 \pm 0.09^{\mathrm{e}}$ & $25.26 \pm 0.81^{\mathrm{a}}$ \\
\hline LSD & 1.26 & 0.18 & 1.53 \\
\hline
\end{tabular}


That means the darkness gradually increased, and yellowness decreased. The $\mathrm{a}^{*}$ values of pan bread crumb contained ajwain increased. Meanwhile, a* values of thyme bread decreased compared to control sample. This observation indicated that pan bread contained ajwain become more redness, while thyme pan bread become more greenness. The observed crumb color corresponds mainly to the natural color of ajwain and thyme powders used (Lee, 2015; Pasrija, et al., 2015 and Zhu et al., 2016).

5. Effect of ajwain and thyme powders on pan bread crumbtexture profile

Hardness is one of the most important parameters to determine bread quality and used as an indicator of bread freshness. The obtained results in Table (6) revealed that hardness was negatively correlated with bread quality. There were gradually increasedin hardness values, but no significant differences in hardness were observed between control sample and other samples, except $\mathrm{T}_{4}$ sample which significantly difference $(\mathrm{p}<0.05)$ was noticed. This increasing probably due to interactions between fibers and gluten (Feiliet al.,2013). Similar increasing trend wasobserved by other previous studies evaluated the effect of ramie powder (Lee and Joo, 2012) and green tea (Ning et al., 2017).

On the other hand, as shown in Table (6) cohesiveness reduced with no significant differences in all pan bread samples were observed compared with the control sample. Similar to bread hardness, there was a significant difference $(\mathrm{p}<0.05)$ on resilience only between control and $\mathrm{T}_{4}$ sample.

Table 6. Effect of ajwain and thyme powders on pan bread textural characteristics

\begin{tabular}{lccc}
\hline \multirow{2}{*}{ Sample* $^{*}$} & \multicolumn{3}{c}{ Textural characteristics } \\
\cline { 2 - 3 } Control & Hardness $(\mathrm{N})$ & Cohesiveness & Resilience \\
A2 $_{\mathbf{A}}$ & $7.50 \pm 0.25^{\mathrm{b}}$ & $0.62 \pm 0.08^{\mathrm{a}}$ & $0.20 \pm 0.01^{\mathrm{a}}$ \\
$\mathbf{A 4}_{\mathbf{T}}$ & $7.62 \pm 0.24^{\mathrm{b}}$ & $0.59 \pm 0.06^{\mathrm{a}}$ & $0.19 \pm 0.01^{\mathrm{ab}}$ \\
$\mathbf{T}_{2}$ & $7.73 \pm 0.10^{\mathrm{b}}$ & $0.59 \pm 0.09^{\mathrm{a}}$ & $0.19 \pm 0.003^{\mathrm{ab}}$ \\
$\mathbf{T}_{4}$ & $7.66 \pm 0.25^{\mathrm{b}}$ & $0.60 \pm 0.09^{\mathrm{a}}$ & $0.19 \pm 0.002^{\mathrm{ab}}$ \\
\hline LSD & $8.19 \pm 0.21^{\mathrm{a}}$ & $0.54 \pm 0.06^{\mathrm{a}}$ & $0.18 \pm 0.003^{\mathrm{b}}$ \\
\hline
\end{tabular}

*Control bread without any addition; $\mathrm{A}_{2}$ and $\mathrm{A}_{4}$ : pan bread containsajwain seed powder $2 \%$ and 4 , respectively. $\mathrm{T}_{2}$ andT 4 pan bread:contain 2 and $4 \%$ thyme leave powder.

Means \pm SD. Mean values in the same column with different superscript letters are significantly different $(\mathrm{P}<0.05)$.

\section{Conclusion}

At level of $2 \%$ replacement insignificant differences observed compared to control, except in color characteristics. These changes due to the natural color of raw materials ajwain seeds and thyme leaves. Substituted at levels up to $6 \%$ were unacceptable by the most of panelists probably due to their after teats and strong aroma.

\section{References}

A.A.C.C. (2000). Approved Methods of the American Association of Cereal Chemists.10th Ed. Vol. II. A.A.C.C. Methods 74-09. American Association of Cereal Chemists. St. Paul, Minn, USA.

A.A.C.C. (2002).Approved Method of American Association of Cereal Chemists, published by American Association of Cereal Chemists, Ins. St. Paul, Minnesota, USA.

Abd El-Megeid, A.A.; AbdAllah, I.Z; Elsadek, M.F. and El-Moneim, Y.F.A. (2009). The protective effect of the fortified bread with green tea against chronic renal failure induced by excessive dietary arginine in male albino rats. World J. Dairy Food Sci., 4(2):107-117.

Ahmed, Z.S. and. Hussein, A. M. S. (2012). Utilization of cinnamon and orange extracts to improve the microbial quality and shelf life of sponge cakes. Aust. J. Basic Appl. Sci., 6(8):665672.

Bialek, M.; Rutkowska, J.; Bialek, A. and Adamska, A. (2016). Oxidative stability of lipid fraction of cookies enriched with chokeberry polyphenols extract. Pol. J. Food Nutr. Sci., 66 (2):77-84

Bolarinwa, I.F.; Aruna, T.E. and Raji, A.O. (2019). Nutritive value and acceptability of bread fortified with moringa seed powder. J. Saudi Soc Agric. Sci., 18:195-200.

Dhillon, G.K.; Ahluwalia, P. and Kaur, A. (2013). Effect of oregano herb on dough rheology and bread quality. Int. J. Food Sci. Nutr. Diet., 2(4):40-44.

Feili, R.; Zzaman, W.; Abdullah, W.N.W. and Yang,T.A. (2013). Physical and sensory analysis of high fiber bread incorporated with jackfruit rind flour. Food sci. Technol., 1(2):30-36. 
Heras-Mozos, R.; Muriel-Galet, V.; LópezCarballo, G.; Catalá, R.; Hernández-Muñoz, P. and Gavara, R. (2019). Development and optimization of antifungal packaging for sliced pan loaf based on garlic as active agent and bread aroma as aroma corrector. Int. J. Food Microbiol., 290:42-48.

Lee, H. andJoo, N. (2012).Optimization of pan bread prepared with ramie powder and preservation of optimized pan bread treated by gamma irradiation during storage. Prev. Nutr. Food Sci., 17:53-63.

Lee, J.H. (2015). Physicochemical and sensory characteristics of sponge cakes with Rubuscoreanus powder.Prev. Nutr. Food Sci., 20(3):204-209.

Maktouf, S.; Jeddou, K. B.; Moulis, C.; Hajji, H.; Remaud-Simeon, M. and Ellouz-Ghorbel, R. (2016). Evaluation of dough rheological properties and bread texture of pearl millet-wheat flour mix.J. food sci. technol.,53(4):2061-2066.

Menon, L.; Majumdar, S.D. and Ravi, U. (2015). Development and analysis of composite flour bread. J. Food Sci. Technol., 52(7):4156-4165.

Mood, B.S.; Shafeghat, M.; Metanat, M.; Saeidi, S. and Sepehri, N. (2014). The inhibitory effect of Ajowan essential oil on bacterial growth. Int. J. Infect., 2(1):e19394.

Nieto, G. (2017). Biological activities of three essential oils of the Lamiaceae family. Medicines,4(3):63-72.

Ning, J.; Hou, G.G.; Sun, J.; Wan, X. and Dubat, A. (2017). Effect of green tea powder on the quality attributes and antioxidant activity of whole-wheat flour pan bread. LWT-Food Sci. Technol., 79:342-348.

Ning, J.; Hou, G.G.; Sun, J.; Zhang, Z. and Wan, X. (2019). Effects of green tea powder on the quality attributes of hard red winter wheat flour and Chinese steamed bread. Int. J. Food Sci. Technol., 54(2):576-582.

Odunlade, T.V.; Famuwagun, A.A.;Taiwo, K.A.; Gbadamosi, S.O.; Oyedele, D.J. and Adebooye, O.C.(2017). Chemical composition and quality characteristics of wheat bread supplemented with leafy vegetable powders. J. Food Qual.,2017:1-7. https://doi.org/10.1155/2017/9536716
Pasrija, D.; Ezhilarasi, P.N.; Indrani, D. and Anandharamakrishnan, C. (2015). Microencapsulation of green tea polyphenols and its effect on incorporated bread quality.LWTFood Sci. Technol.,64(1):289-296.

Peng, X.; Ma, J.; Cheng, K.W.; Jiang, Y.; Chen, F. and Wang, M. (2010). The effects of grape seed extract fortification on the antioxidant activity and quality attributes of bread. J. Food chem., 119(1):49-53.

Saranraj, P. and Geetha, M. (2012). Microbial spoilage of bakery products and its control by preservatives. Int. J. Pharm. Biol. Arch., 3(1):3848.

Schmiele, M.; Jaekel, L.Z.; Patricio, S.M.C.; Steel, C.J. and Chang, Y.K. (2012). Rheological properties of wheat flour and quality characteristics of pan bread as modified by partial additions of wheat bran or whole grain wheat flour. Inter. J. Food Sci. Technol., 47:2141-2150.

Seleem, H.A. and Mohamed, Z.E.O.M. (2014). Influence of some medicinal and aromatic plants addition on pan bread quality. World J. Dairy Food Sci., 9(2):299-307.

Singh, G.; Maurya, S.; Catalan, C. and De Lampasona, M.P. (2004). Chemical constituents, antifungal and antioxidative effects of ajwain essential oil and its acetone extract. J. Agric. Food. Chem., 52(11):3292-3296.

Snedecor, G.W. and Cochran, W.G.(1982). Statistical Methods. $6^{\text {th }}$ ed.,Iowa State Univ., Press,Iowa, U.S.A.

Vasileva, I.;Denkova，R.;Chochkov，R.;Teneva, D.;Denkova, Z.;Dessev, T.;Denev, P. and Slavov, A. (2018). Effect of lavender (Lavandula angustifolia) and melissa (Melissa Officinalis) waste on quality and shelf life of bread. Food Chem., 253:13-21.

Wójcik, M.; Dziki, D.; Biernacka, B.; Różyło, R.; Miś, A. and Hassoon, W.H., (2017). Effect of the addition of mixture of plant components on the mechanical properties of wheat bread. Int.Agrophys., 31(4):563-569.

Zhu, F.; Sakulnak, R. and Wang, S. (2016). Effect of black tea on antioxidant, textural, and sensory properties of Chinese steamed bread. Food chem., 194:1217-1223. 


$$
\begin{aligned}
& \text { تأثير نبات الأجوين على جوده خبز القوالب }
\end{aligned}
$$

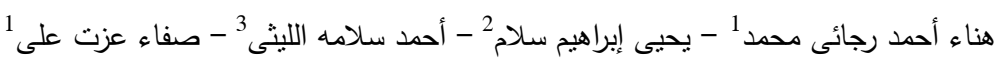

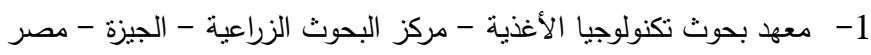

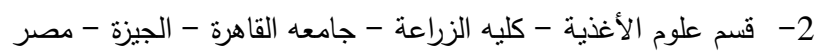

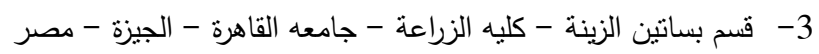

تم دراسـة تأثير إضـافة نبات الأجوين وأوراق الزعتر على مدى القبول العام وجودة خبز القوالب. تم إستبدال دقيق القـح بمسـحوق

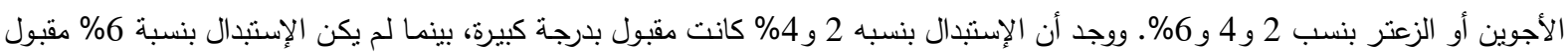

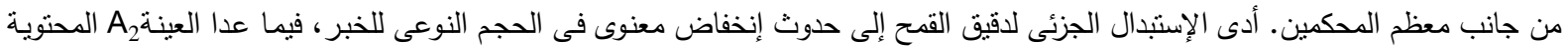

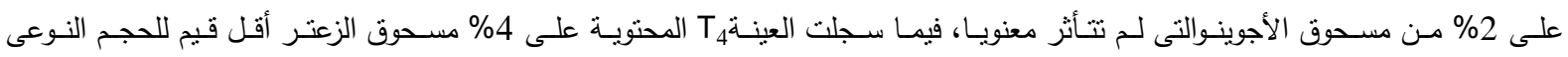

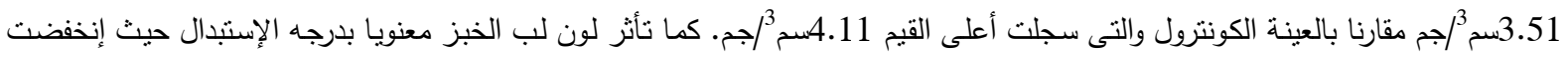

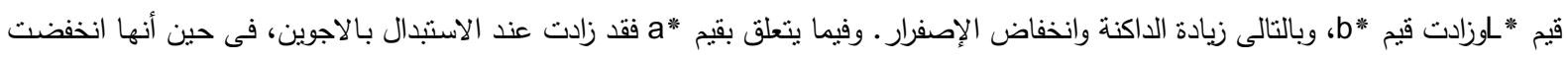
فى حاله الاستبدال بالزعتر، وتتثير النتائح المتحصل عليها أن لب الخبز المحتوى على الأجوين أصبح أكثر احمرار ، فى حين أن الخبز المحتوى

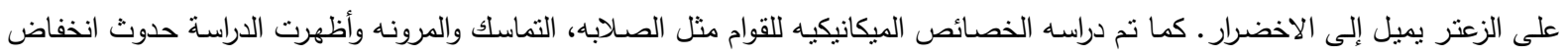
غير معنوى فى الصلابة والمرونـقفيما عدا المعاملة T والتى حدث لها إنخفاض معنوى وقد سجلت 8.19 نيوتن و 0.18 كقيم للصدابة والمرونـة

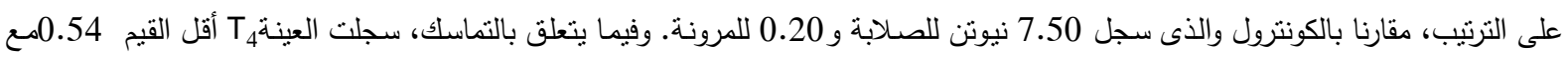

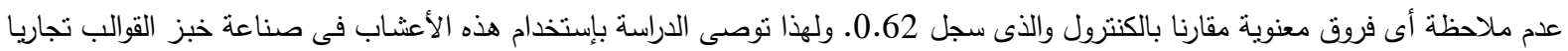
من أجل الحصول على منتج عالى الجودة.

الكلمات المفتاحية: خبز القوالب، الأجوين، أوراق الزعتر ، الخواص الحسية، الصفات الفيزيائيه. 
